\title{
Game theory and port economics: a survey of recent research
}

\begin{abstract}
The last decade has seen a significant upsurge of studies seeking to examine the impacts of port agents' strategic decisions. The outcome has been a wide range of results and conclusions. The aim of this work is to provide a review of this recent research in the port industry that uses strategic interaction approaches from industrial organization and game theory. The paper concentrates on five topics: ownership, relationship between ports and their hinterlands, port authorities and port operators' relations, capacity investment decisions and port specialization. We present the objectives, methodologies and results of the papers reviewed, with special emphasis on how models are developed. The results are not always consistent between the works analyzed. On the one hand, this could be due to the complexity of the port industry and the high number of agents that intervene. Researchers need to simplify reality to build their models by imposing restrictive assumptions. On the other hand, results could be very sensitive to the techniques used or to the differences on the port environment of the countries of study. However, some conclusions can be extracted and they present a good starting point to develop more sophisticated models. Finally, we also propose avenues for future research.
\end{abstract}

Keywords: ports, game theory, industrial organization, transportation. 


\section{Introduction}

Globalization, the growth of international trade and the relocation of the main centers of production and consumption have resulted in the need to create new more reliable and efficient supply chains, providing new opportunities for shipping lines, terminals, and other transport operators. These logistic models are continuously evolving. Consequently, transport firms have had to re-evaluate the scope of their activities in response to structural changes in logistics (Kaselimi et al. 2011). Ports are the main elements of many of these supply chains because of their position as gateways or/and transshipment centers. As a result, ports have become complex centers where many of the main functions within the supply chains are developed.

Technological developments in the port industry, such as containerization or improvements in communication systems, have reduced transport cost and times, improving schedule reliability. Moreover, the rising importance in international trade of emerging economies, such as China or the countries of Southeast Asia, whose exports represented approximately $35 \%$ of global exports in 2010 (European Central Bank, Emerging Economies), have intensely increased demand for port services and competition between ports. These new developments and trade by ports, which are losing their monopolistic position over the hinterlands because they increasingly overlap with one another have enlarged the reach of markets served. This growth of cargo movements and competition has been accompanied by a wave of privatization through devolution policies around the world which has stimulated further inter-port and intra-port competition.

These new developments and trends which occurred in the last fifty years have attracted much scholarly attention. This has resulted in an increase in port studies which have led to scope a wide branch of issues and methodologies. We can find empirical or/and theoretical analysis that use different approaches depending on the analyzed issue (frontier models, descriptive and cluster analysis, principal component analysis, game theory, industrial organization...). Otherwise, the most common studied issues in port literature are the following ones: terminal operators, ports in supply chains, port governance, port planning and development, port policy and regulation, port competition and competitiveness, spatial analysis of sea ports, port selection, productivity and efficiency, and cooperation, merging and alliances. For an extended review of port studies, see Chang and Lee (2007) and Pallis et al. (2011).

Game theory allows us to study most of the issues mentioned above from a strategic point of view. It makes it possible to theoretically analyze the effects of port management decisions such as investments, price policies, and ownership on profits, on social welfare and on the competitive position of ports. This information represents a useful decision tool for policy makers, managers, and other agents. Due to these advantages, in recent decades, great progress has been made in the application of game theory to transportation analysis, with research in the airport sector the first to apply this approach in the early 1970s (Levine, 1969 and Carlin and Park, 1970). Since then, the air sector has been widely and successfully analyzed using strategic interaction approaches. However, with the exception of the studies of Yang $(1995,1996,1998$ and 1999) in the late 90s, it was not until the last decade that game theory was applied widely to port sector analysis.

Therefore, with this study, we seek to provide a survey of recent research that applies game theory approaches to the port industry to outline the topics discussed, methodologies used and results obtained. Due to the scope of the field, we focus on those studies exclusively 
related to governments, port managers and terminal operators, so we abstract away from other agents related with port activities such as shipping lines, truck companies... We expect this survey to be a useful guide for future research in this field and, at the same time, useful for port managers or policy makers in shaping their decision processes differently.

The paper is organized by topic as follows. Section 2 surveys works that analyze the effects of port ownership. Section 3 focuses on studies that relate ports with their hinterlands. Section 4 analyzes port relations and integration processes in the port industry. Section 5 reviews papers that study the strategic investment decisions in capacity. Section 6 reviews port specialization. Finally, conclusions are presented in section 7.

\section{Ownership effects and competition}

The governance of ports has changed dramatically since the 1980s. As a result, private operation of port facilities is increasingly common, particularly government devolution programs. We can understand devolution as "the transfer of functions or responsibility for the delivery of programs and services from the federal government to another entity" (Rodal and Mulder, 1993). Devolution leads ports around the world to move away from a public management model to other methods of organization, such as mixed forms of ownership and/or management models that combines public and private participation in port activities, with the landlord port model one of the most popular options. Although reform objectives vary, the main reasons discussed are the following: first, private port operation is considered possibly more cost and technically efficient (Tongzon and Heng, 2005); second, private ownership may raise the competitive position of a port (Midoro et al., 2005); third, there might also be strategic reasons, with governments opting for privatization to increase port profits as part of the national welfare (Czerny et al. 2014). Moreover, Brooks (2004) notes that increasing deficit, accumulated debt burdens and low levels of public confidence in government could force governments to find ways to do more with fewer resources. Finally, Xiao et al. (2012) add reducing bureaucracy and public investment as other reasons for devolution. However, does devolution actually have these effects?

In this section, we review the literature on strategic choice of ownership of port facilities. The studies of Czerny et al. (2014), Matsushima and Takauchi (2014) and Xiao et al. (2012) analyze the effects of ownership on port charges ${ }^{1}$, investment, profits and welfare in a competitive environment. Figure 1 shows the model structure used in the papers of Czerny et al. (2014) and Matsushima and Takauchi (2014). The main differences between these papers are, on the one hand, that Czerny et al. (2014) and Matsushima and Takauchi (2014) only consider private or public owned ports, whereas Xiao et al. (2012) include scenarios with partially privatized ports because real world experiences suggest that after port privatization, in many cases, governments maintain a certain degree of influence on port operation or strategic investment decisions. On the other hand, Xiao et al. (2012), unlike Czerny et al. (2014) and Matsushima and Takauchi (2014), do not analyze the decision whether to privatize ports, focusing only on the effects of ownership, considering ownership strategies exogenous. These studies are summarized in table 1 . To do so, Xiao et al. (2012) propose an integrated economic model in which the effects of different forms of ownership on port charges and capacity investment are analyzed. Moreover, these authors consider the case of either monopoly or oligopoly. This model is based on a one-stage game where the owners of port facilities simultaneously decide port charges, capacities and quantities that maximize the objective function that depends on the form of ownership (Figure 2). 
Figure 1: Model structure of Czerny et al. (2014) versus Matsushima and Takauchi (2014)
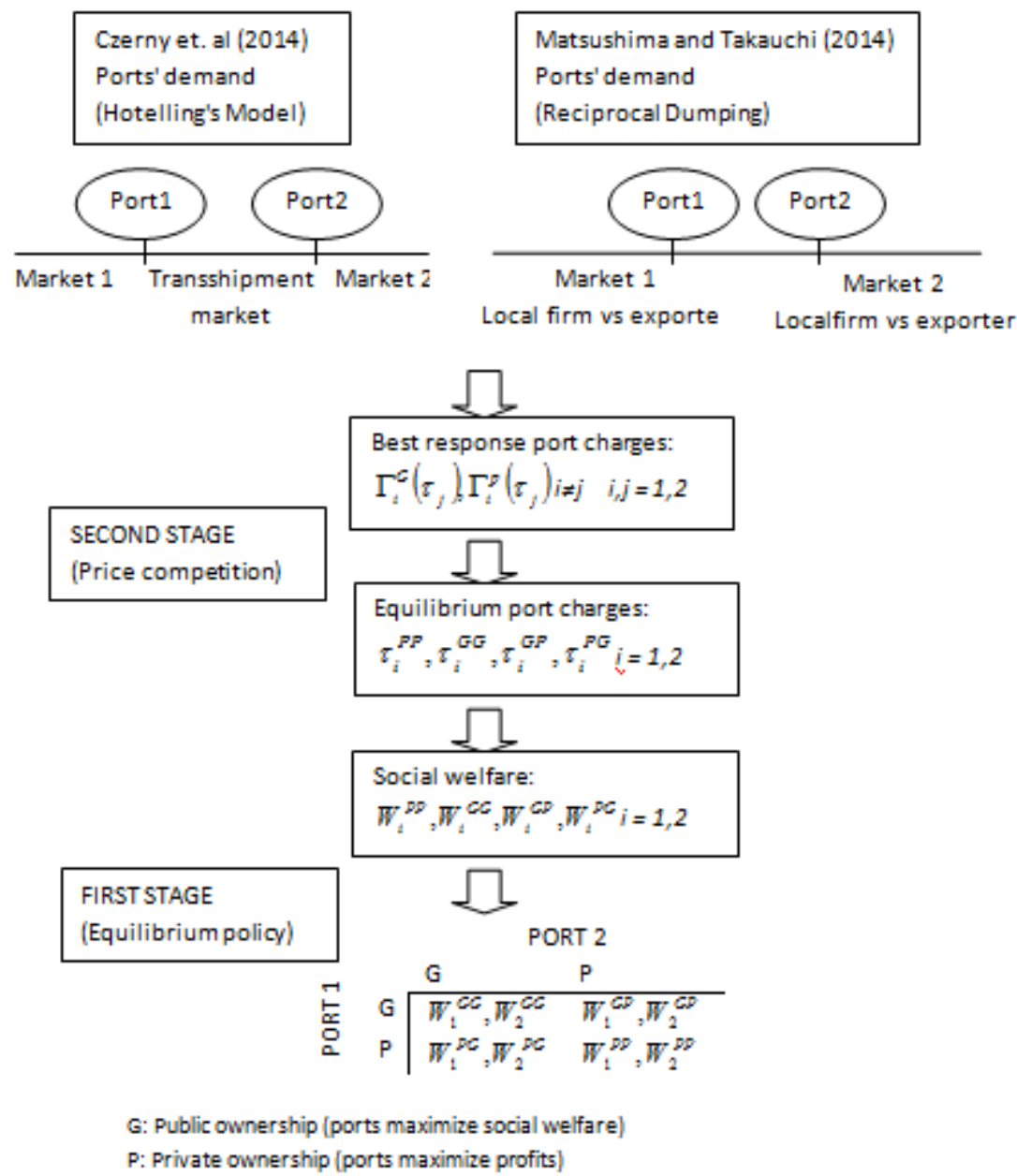

Source: Czerny et al. 2014 and Matsushima and Takauchi 2014

Figure 2: Objective function of the different forms of ownership (Xiao et al., 2012)

\begin{tabular}{|c|c|}
\hline Port manager & Objective function \\
\hline Private firm & Maximization of port profits \\
\hline Local government & $\begin{array}{c}\text { Maximization of local profits } \\
\text { (port profit + spillovers to the local } \\
\text { economy) }\end{array}$ \\
\hline Central government & $\begin{array}{c}\text { Maximization of social welfare } \\
\text { (port profit + spillovers to the local } \\
\text { economy + consumer surplus) }\end{array}$ \\
\hline
\end{tabular}

Source: Xiao et al. (2012)

The methodology used by Czerny el al. (2014) differs from that used by Xiao et al. (2012). Czerny et al. (2014) consider two ports belonging to two different regions. These ports are competing, and each regional government must decide whether to privatize the facility in its region. A two-stage game is modeled; in the first stage, governments make the privatization decision simultaneously to maximize the regional welfare measured as the sum of net benefit of local consumers and port's profit; in the second stage, they set port charges that maximize 
ports' objective functions. By comparing the results of all possible scenarios in the second stage, the ownership is determined taking into account rival ports' behavior. Furthermore, a third region is included in their model, with both ports competing for transshipment traffic. In this way, port demand function is obtained by applying the Hotelling model, including the three regions.

Matsushima and Takauchi's (2014) model is similar to that of Czerny et al. (2014), except that these authors neither include a transshipment market nor obtain port demand from the Hotelling model, but do apply a reciprocal dumping model. Their model comprises of two countries, with each containing a port and a firm that serves the two markets; therefore, in each country, there are two homogeneous firms competing. When a firm exports, it must use both ports, incurring a transportation cost composed of the shipping price and the port charges. Finally, public owned ports set port charges to maximize national welfare, while private owned ports to maximize their profits. In this paper, national welfare consists on consumer surplus, port's profit and local firm's profit. An important assumption is that ports cannot discriminate between firms regarding port charges. A three-stage game is developed: in the first stage, governments decide independently whether to privatize their ports; secondly, ports independently set their port charges; and thirdly, the two firms simultaneously compete in quantity in both markets. They analyze equilibrium outcomes under different assumptions: homogeneous market size, heterogeneous market size, and, the case in which ports engage in cost reduction activities after the ownership structure is determined.

Xiao et al. (2012) and Czerny et al. (2014) find that private owned ports set higher port charges than public owned ones. Furthermore, Czerny et al. (2014) show that strategic complementarity in pricing decisions occurs when both ports are privately operated. This complementarity leads to greater exploitation of the transshipment market but reduces consumer surplus in the national market, which could be compensated with higher port profits. Therefore, if the transshipment market is sufficiently large, then the incentives to privatize both ports are strong. In contrast, Matsushima and Takauchi's (2014) model shows that public owned ports can set higher port charges than private owned ones when transport costs are high to protect the domestic firm. These port charges are strategic substitutes independent of port ownership. These authors find that, in equilibrium, both ports choose the same ownership strategy. Despite using quite similar models, the results obtained by Czerny et al. (2014) and Matsushima and Takauchi (2014) are conflicting. This would indicate that their results depend heavily on the demand functions.

Regarding investment decision and congestion, Xiao et al. (2012) find that the larger the share of private ownership is, the less the capacity investment is. When a local government is involved, the greater spillover effects a higher capacity investment. These investments are higher when ports are coordinated by a central government than when these ports compete. This result cannot be generalized due to the fact that many governments face severe budgetary constraints which do not allow them to undertake certain investments that may be necessary. To conclude, the authors find that fully private and partially private ports present the same level of congestion, which is lower than ports managed by a central government. The first result could not be in line with practice. This could be because of two issues. First, the objective functions of private port managers and local governments only differ in the inclusion of spillover effects (figure 2). Second, differences in the operational efficiency between private and public management are not considered to measure congestion. 
Although these authors take into account that congestion depends on port operations, capacity and operation efficiency, they do not allow differences in efficiency according to the various types of ownership in ports. However, in practice, private and public owned ports could not present the same levels of efficiency (Cheon et al. 2010). In general terms, the only difference considered between private and public-owned ports in these studies is their objective function. However, this implicit assumption could generate biased results. As we previously mentioned, it is considered that private firms could be more efficient than public ones due to their capacity to control costs. This fact is related with the concept of $X$ efficiency (Leibenstein, 1966). In this sense, those firms with more competitive pressures manage to operate at lower costs which can lead to increases in labor productivity and savings associated to the use of inputs which in turn affects the firms' profits.

Finally, an interesting future research area would be the study of the effects of the different types of port ownerships on the strategies of vertical relations between infrastructure and port services. 


\section{Table 1: Summary of ownership effects and competition}

\begin{tabular}{|c|c|c|c|c|}
\hline Study & Objective & Forms of ownership & Methodology & Results \\
\hline $\begin{array}{l}\text { Czerny et al. } \\
2014\end{array}$ & $\begin{array}{l}\text { Analyzing the decision } \\
\text { whether to private ports }\end{array}$ & $\begin{array}{ll}\text { - } & \text { Ports fully public } \\
\text { - } & \text { Ports fully privatized }\end{array}$ & $\begin{array}{l}\text { Two-stage game: } \\
\text { 1. First stage: ports decide simultaneously } \\
\text { whether to privatize, maximizing social } \\
\text { welfare } \\
\text { 2. Ports set port charges competing in } \\
\text { price }\end{array}$ & $\begin{array}{l}\text { Private ports set higher port charges. } \\
\text { A reduction of consumers' operational cost implies higher } \\
\text { port charges, ceteris paribus. } \\
\text { If transshipment market size is large enough, privatizing } \\
\text { both ports will achieve Nash equilibrium. }\end{array}$ \\
\hline $\begin{array}{l}\text { Matusushima } \\
\text { and Takauchi. } \\
2014\end{array}$ & $\begin{array}{l}\text { Analyzing the decision } \\
\text { whether to privatize } \\
\text { ports }\end{array}$ & $\begin{array}{l}\text { - } \quad \text { Ports fully public } \\
\text { - } \quad \text { Ports fully privatized }\end{array}$ & $\begin{array}{l}\text { Three-stage game: } \\
\text { 1. Governments decide simultaneously } \\
\text { whether to privatize, maximizing social } \\
\text { welfare } \\
\text { 2. Governments set port charges } \\
\text { 3. Firms compete following a reciprocal } \\
\text { dumping. }\end{array}$ & $\begin{array}{l}\text { Strategic privatization decision depends on transportation } \\
\text { costs. } \\
\text { All possible equilibrium ownership outcomes are } \\
\text { symmetrical. } \\
\text { The government of the largest country has strong } \\
\text { incentives to nationalize its port. }\end{array}$ \\
\hline Xiao et al. 2012 & $\begin{array}{l}\text { Analyzing the effects of } \\
\text { port ownership }\end{array}$ & $\begin{array}{l}\text { - Ports fully public } \\
\text { - Ports fully privatized } \\
\text { - Partnership between: } \\
\quad \text { Public (local or central) } \\
\quad \text { ownership } \\
\text { O Private ownership. }\end{array}$ & $\begin{array}{l}\text { Given that objective function depends on } \\
\text { the form of ownership: } \\
\text { Ports simultaneously set port charges, } \\
\text { output and capacity (in competitive } \\
\text { environments taking into account } \\
\text { competitors' behavior) }\end{array}$ & $\begin{array}{l}\text { The greater private investor control is, the less capacity } \\
\text { investment is. } \\
\text { A greater spillover effect implies higher capacity } \\
\text { investment. } \\
\text { Ownership does not affect congestion when competition } \\
\text { does not exist. However, if there are competing ports, } \\
\text { owned by a central government, then they will present } \\
\text { higher levels of congestion }\end{array}$ \\
\hline
\end{tabular}




\section{Relations between ports and hinterlands}

Containerization and devolution have intensified port competition, dramatically increasing the movement of cargo; consequently, many ports and their respective hinterland infrastructures around the world, especially hinterland road systems, are increasingly congested (Yuen et al., 2008). Additionally, the nature of port competition has changed over recent decades from a competitive structure involving individual ports or shipping companies to one implicating full maritime logistic chains (Suykens and Van de Voorde, 1998). Therefore, the port is just one node in any particular supply chain, and its attractiveness depends not only on its own infrastructure or performance but also on other factors related to the logistic chain to which it belongs. According to Van de Voorde and Vanelslander (2009), a maritime logistic chain consists of three sections: the purely maritime activities, the handling of goods in the port, and the hinterland transport services. Thus, the distribution within the hinterland is an important element of the competitive strength of a port. In this way, if we consider a port a node of a logistic chain, improving not only port but also hinterland accessibility, then the delay costs of using that port will be reduced and its competitiveness improved.

These facts have motivated several studies to seek to theoretically analyze the effect of hinterland conditions on port performance, demand and profits. In this group, we find the papers of De Borger et al. (2008), Zhang (2008), Wan and Zhang (2013) and Basso et al. (2013). These studies are summarized in table 2 . The first three studies are similar in methodology and objectives. All investigate the impact of hinterland access conditions on port competition, considering a congestible hinterland. The main differences among them are the following ones: first, De Borger et al. (2008) consider congestible port facilities, analyzing the effects of the capacity investment decision on port and hinterland. Second, Wan and Zhang (2013) abstract away port congestion, while road tolls are considered endogenous variables; therefore, both hinterland capacity and road tolls are set by governments in a first stage. Third, Zhang (2008) separately represent hinterland access infrastructures, dividing them into those specifically for sea cargo and those used by both freight trucks and local commuter cars. Figure 3 shows the model structures used in the papers of De Borger et al. (2008), Zhang (2008) and Wan and Zhang (2013). These three studies propose a two-stage game for two competing ports located in different countries. In the first stage, governments decide the optimal capacity levels of facilities and road tolls that maximize the social welfare of their respective countries, taking into account the ports' pricing behavior. Then, in the second stage, privately operated ports set port charges, taking into account potential congestion at facilities. Nash equilibrium port charges are set by a price competition model in the case of Borger et al. (2008); in contrast, Wan and Zhang (2013) assume that ports compete in quantity, whereas Zhang (2008) considers the possibility of both price and quantity competition. 
Figure 3: Model structure of Borger et al. (2008), Zhang (2008) and Wan and Zhang (2013).

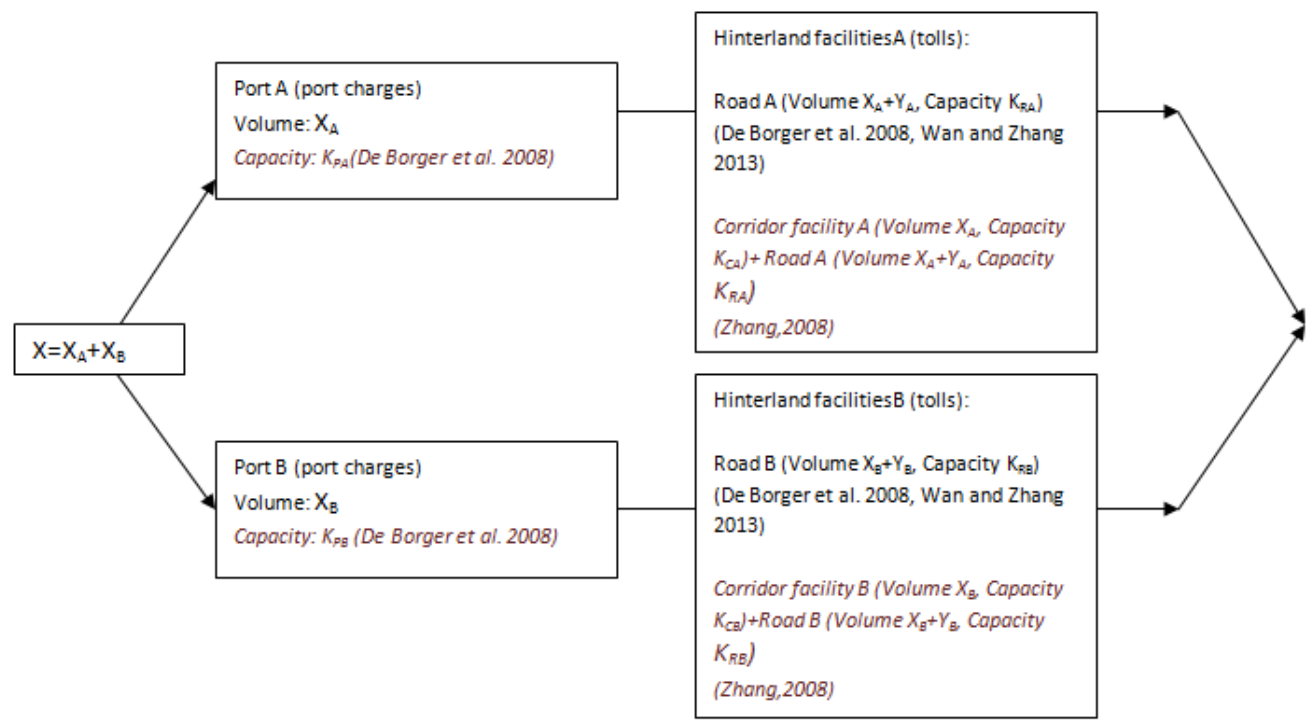

Regarding the results, Borger et al. (2008) find that investment in port capacity induces both ports to reduce port charges. However, improving hinterland accessibility raises demand and congestion; therefore, it increases the port charges of the port that uses this infrastructure but reduces competitors' port charges. A similar result is achieved by Zhang (2008) but only in the case of the specific facility for sea cargo. Thus, Borger et al. (2008) conclude that governments have stronger incentives to invest in hinterland than in port capacity, increasing capacity until the marginal profits of those increments equal the unit cost of that capacity. However, Zhang (2008) finds that when ports compete in quantity, investments in the sea cargo-specific corridor of one port increases the output and profits of that port and reduces competitor output, while investments in roads have an undetermined effect. 
Table 2: Summary of relations between ports and hinterlands.

\begin{tabular}{|c|c|c|c|c|}
\hline Study & Objective & Model structure & Methodology & Results \\
\hline $\begin{array}{l}\text { Borger et al. } \\
2008\end{array}$ & $\begin{array}{l}\text { Modeling the r optimal } \\
\text { decisions } \\
\text { investment in port facilities } \\
\text { and hinterland accessibility. }\end{array}$ & $\begin{array}{l}\text { - Two congestible ports competing } \\
\text { - A common hinterland } \\
\text { - A congestible road used by hinterland's } \\
\text { commuter traffic. }\end{array}$ & $\begin{array}{l}\text { Two-stage game: } \\
\text { 1. Governments simultaneously decide } \\
\text { ports and hinterlands capacity, } \\
\text { maximizing social welfare. } \\
\text { 2. Ports set port charges competing in price }\end{array}$ & $\begin{array}{l}\text { Investment in port capacity reduces port } \\
\text { charges. } \\
\text { Investment in hinterland accessibility increases } \\
\text { port charges of its port and reduces those of } \\
\text { rival ports. }\end{array}$ \\
\hline Zhang 2008 & $\begin{array}{l}\text { Investigating the effects of } \\
\text { hinterland accessibility on port } \\
\text { competition linking port } \\
\text { competition with urban } \\
\text { mobility. }\end{array}$ & $\begin{array}{l}\text { - Two ports competing } \\
\text { - A common hinterland } \\
\text { - Two congestible facilities, one road used } \\
\text { by commuter traffic and the other only } \\
\text { used by port traffic. }\end{array}$ & $\begin{array}{l}\text { Two-stage game: } \\
\text { 1. Governments simultaneously decide on } \\
\text { road and corridor facility capacity, } \\
\text { maximizing social welfare. } \\
\text { 2. Ports set port charges competing in price } \\
\text { and quantity }\end{array}$ & $\begin{array}{l}\text { Investment in port corridor capacity increases } \\
\text { port charges of its port and reduces those of } \\
\text { rival port. } \\
\text { Investment in road capacity has an } \\
\text { undetermined effect. }\end{array}$ \\
\hline $\begin{array}{l}\text { Wan and } \\
\text { Zhang } 2013\end{array}$ & $\begin{array}{l}\text { Developing a model to analyze } \\
\text { rivalry between alternative } \\
\text { intermodal transportation } \\
\text { chains. }\end{array}$ & $\begin{array}{l}\text { - Two ports competing } \\
\text { - A common hinterland } \\
\text { - A congestible road used by hinterland's } \\
\text { commuter traffic. }\end{array}$ & $\begin{array}{l}\text { Two-stage game: } \\
\text { 1. Governments simultaneously decide on } \\
\text { hinterland capacity and road tolls, } \\
\text { maximizing social welfare. } \\
\text { 2. Ports set port charges competing in } \\
\text { quantity. }\end{array}$ & $\begin{array}{l}\text { Investment in road capacity, increases port } \\
\text { charges, demand and profits (with the } \\
\text { opposite effect on the rival port). }\end{array}$ \\
\hline $\begin{array}{l}\text { Basso et al. } \\
2013\end{array}$ & $\begin{array}{l}\text { Investigating strategic } \\
\text { investment decisions. }\end{array}$ & $\begin{array}{l}\text { - Three independent governments, three } \\
\text { regions, two with a port and a common } \\
\text { hinterland. } \\
\text { - Port regions compete for the } \\
\text { transshipment traffic of the third. } \\
\text { - Any combination of coalitions between } \\
\text { governments is possible. }\end{array}$ & $\begin{array}{l}\text { Two-stage game: } \\
\text { 1. Governments simultaneously decide on } \\
\text { capacity of accessible facilities under } \\
\text { different forms of coalition. } \\
\text { 2. Ports set port charges competing in price } \\
\text { that maximize their regions' social } \\
\text { welfare. } \\
\text { (Port demand is obtained by Hotelling's } \\
\text { model) }\end{array}$ & $\begin{array}{l}\text { Coalition between port regions implies less } \\
\text { investment in these regions than no coalition. } \\
\text { Coalition between one port region and the } \\
\text { third region implies higher level of investment } \\
\text { than coalition between port regions. } \\
\text { Coalition among three regions implies higher } \\
\text { investment in port regions and lower } \\
\text { investment in the third region than non- } \\
\text { cooperation. }\end{array}$ \\
\hline
\end{tabular}


Wan and Zhang (2013) find that road capacity investment increases a port's output, port charges and profits, having the opposite effect on its rival, reducing road congestion in both chains and creating a positive externality across both regions. The effects of road tolls on port competition depend on the toll's mechanism. First, with discriminative tolls, an increase in commuter tolls has the same effect as road capacity on output, port charges, profits and congestion. In contrast, a decrease in truck tolls raises output, charges, profits, and road congestion, causing the opposite effect on its competitor's logistic chain. Second, an increase in non-discriminative tolls has the same effect as capacity investment if and only if the difference between the delay cost to shippers and commuters is sufficiently small.

On the other hand, Basso et al. (2013) also study this topic, although from a different point of view. They consider two seaports with their respective captive markets and a common hinterland for which the seaports compete. The two seaports and the common hinterland belong to three independent local governments, which determine the level of investment in their own regional transportation systems in the first stage of the game. When governments invest four scenarios are considered. In the first, there is no cooperation among governments. The other three scenarios present three different forms of coalition: a coalition between the port regions' governments, a coalition between a port region government and the common hinterland government and finally, a coalition among the three regions' governments. In the second stage of the game, public owned ports set port charges that maximize national welfare taking into account their competitors' behavior. Basso et al. (2013) show the following results. On the one hand, improving the infrastructure of a region with a port reduces its port charges and profits, increases its consumer surplus, and also reduces competitors' charges, although to a lesser extent. Meanwhile, investment in the common hinterland leads ports to set lower port charges, which makes the port with the lower charges and better accessibility more attractive, increasing its demand. However, the effect on profits is undetermined because the incomes are reduced due to the lower port charges. In contrast, the welfare of the other port is reduced. On the other hand, by analyzing the different types of cooperation among governments, the authors conclude that coalitions between port regions lead to lower levels of investment than in cases of non-cooperation and cooperation between the common hinterland government and a port region government. Otherwise, cooperation among the three governments leads to higher levels of investment in port regions and lower levels in the common hinterland region than in the case of non-cooperation. The net effect on the welfare of total cooperation is positive, increasing in the common hinterland region and decreasing in the port regions.

Studies analyzed in this section set the optimal level of hinterland and/or port infrastructure. From their results, it can be seen that investment in one region's facilities affects port profits and welfare of the neighbor region. So, we could expect some type of reaction from governments to neighbor's investment in order to reduce its negative effects on port profits and social welfare, especially when ports are competing. So, the optimal level of capacity could depend on the rival's capacity, as there is a strategic interdependence among regions' investments. Including this type of response could make the model more general and complete.

Finally, in line with these studies, it would be interesting to analyze inter-port competition with the same hinterland. Currently many regions have several ports competing and these ports have to share the same infrastructures. Furthermore, this analysis could lead to study the circumstances under which these ports located in the same region would prefer to cooperate instead of competing. 
4. Port authorities and terminal operators: vertical relations and horizontal integration processes

Devolution has amplified private participation in port operations, leading ports to pursue vertical separation of pure port services. As a result, in most cases, port authorities maintain management of port infrastructures, with private companies providing the remaining services. This new framework has expanded the number of players in port operations, such as port authorities, terminal operators, shipping liners, and transport companies, leading to new types of relations among these entities. In this way, we find two clearly differentiated trends in port systems around the world. The first is a well-known trend that began in the mid-1980s; in that trend, a global wave of port privatization was caused mainly by the need for private financing of infrastructure and revamping of port operations to address an increasingly competitive environment (Midoro et al. 2005), which led ports to vertically separate many port services. The second is a new and growing trend featuring new forms of partnership among private port agents (Soppé et al. 2009). Several studies use game theory to explain these new relations and their effects. Some analyze the vertical relations between port authorities and terminal operators, while others focus on the new partnerships between private operators.

\subsection{Vertical relations between port authorities and private operators}

Due to governments around the world have stimulated the participation of private companies in port services, especially in the ownership and operation of port terminals, Van Reeven (2010) has developed a model to analyze the effect of intra-port competition on economic sea rents. His model includes two competing ports, each managed by a port authority. In this context, Van Reeven (2010) assumes that these ports could be either integrated ports or landlord ports. This assumption leads to three possible scenarios: two landlord ports competing, two integrated ports competing, and finally, a landlord port competing with an integrated port. In a landlord port, several private terminal operators compete in the port and set prices, and the port authorities set their port charges simultaneously, taking into account occurrences in the competitor port. In contrast, in an integrated port, all activities are conducted by the port authority, which sets its port charges taking into account the competitors' behavior. In that way, the model has the following structure: first, port authorities decide whether to allow private participation in port services; and second, port authorities and terminal operators simultaneously set port charges and prices, respectively, by competing in quantity. In this way, it would be interesting to model this second stage as a leader-follower game, i.e., firstly, port authorities set port charges, and then terminal operators choose prices taking port charges as given. Finally, ports' demands are obtained by a Hotelling model. Comparing the results of these scenarios, Van Reeven (2010) finds that being a landlord port is a Nash equilibrium. Private participation in port operation raises port charges and profits in the entire sector because port charges are strategic complements. Finally, if the number of private terminal operators tends to infinity, then the profits of a landlord port are equal to those of an integrated port. Therefore, the port industry has no incentive to introduce intra-port competition because the lesser number of private terminal operators competing in a port, the higher profits for that port.

Following with an analysis of the effects of intra-port competition, Kaselimi et al. (2011) examine how dedication of existing terminal capacity for exclusive use by a specific customer or group of customers affects the prices and profits of both port authorities and terminal operators. They use a model similar to that of Van Reeven (2010). Again, there are two competing ports managed by their respective port authorities. In each port, there are several terminal operators. From a linear Hotelling model with fixed localization at the extremes, they obtain ports' demands and develop a 
one-stage quantity-price game. Using this model, they compare the results obtained analytically in the two possible scenarios: with and without a dedicated terminal ${ }^{2}$. Dedicating an existing terminal in a port implies that a percentage of the demand of this port goes only to the dedicated terminal, and the rest is satisfied by the multi-user terminal providers. On the other hand, the number of competing terminals is reduced because one has become dedicated. To test the model, Kaselimi et al. (2011) carry out a numerical simulation collecting data based on estimations for the ports of Antwerp and Rotterdam in the Rhine-Schelt Delta for the year 2007. These authors find that dedication of a terminal will lead to lower profits for the port authority because, in this model, profits represent only those coming from the multi-user terminals. Measuring port authority's profits from a dedicated terminal would allow these authors to determine the circumstances under which port authorities have incentives to dedicate existing capacity. This analysis might complete the model. Moreover, under the assumption that the capacity dedicated is higher than demand extracted from multi-user terminals, the numerical simulation shows that multi-user operators are able to keep a substantial portion of the demand in their port and still increase their profits. Therefore, they are not negatively affected by the introduction of a dedicated terminal. Finally, the users of multi-user terminals always lose when an existing terminal is dedicated because terminal operators increase their prices, and congestion problems can appear.

Yu and Shan (2013), in contrast, abstract away intra-port competition, focusing on inter-port competition and vertical relations between governments and private terminal operators, allowing for the possibility of horizontal integration between terminal operators. Again, they model a framework of two ports competing for container traffic, with one terminal operator located in each port. This model includes both competition between ports or governments and between the two terminal operators. Furthermore, as stated earlier, these authors consider different terminal competition intensities: in one scenario, these terminals are operated by two different companies, and in the other, they are operated by the same company. For this purpose, a three-stage game is modeled. In the first stage, port authorities set port charges that maximize their profits. In the second, port operators determine the quality of their services to maximize their profits; if private operators own the same company, then the quality is determined in a centralized way. Finally, private operators set their prices with the aim of maximizing profits again. This game is solved by backwards induction. Furthermore, from a Hotelling model in which ports are not located in the extremes existing dedicated demand, port demands are derived for the analysis. A numerical simulation is then carried out to test the model. In practice, when two terminal operators are managed by the same company, strategic decisions such as quality and prices are usually made in a centralized way. Therefore, an interesting option could be that in the third stage of the game, terminal operators set prices in order to maximize the joint profit when centralized management was considered. The main results suggest that governments' profits are lower when two terminals are centralized. Therefore, governments prefer that port terminals compete rather than centralize. In contrast, if one terminal has relatively fewer advantages in its service quality than the other, it will prefer service centralization because it can share the relative advantages of the other terminal.

The above works study the relations between port authorities and port terminals; however, none analyzes the bases of the agreements or concessions that allow private firms to conduct port operations. Wang and Pallis (2014) study post-contractual moral hazard problems with port concession agreements, Yip et al. (2014) analyze the effects of competition on these agreements and Saeed and Larsen (2010) focus on the inverse effects, i.e., the concession agreements' effects on inter-port and intra-port competition. 
Wang and Pallis (2014) develop a game theory framework to identify post-contractual moral hazard problems and analyze fixed lump-sum fees and performance-based fees as solutions by which Port Authorities' interests are aligned with those of terminal operators. To do so, they model one terminal operator that has private information about its influence on the quantity of handled cargo, which greatly affects the port authority's welfare. This quantity of services depends positively on the terminal operator management effort, which implies a cost for the private operator. Regarding fees, on the one hand, if the concession agreement is awarded for a fixed fee, then the terminal operator must pay in the first year of the concession. Moreover, a minimum throughput guarantee is imposed by the port authority; if this guarantee is not satisfied, then the awarded concession will terminate. From this assumption, the researchers compare the actual value of the terminal operator's profits from fulfilling the concession agreement with the case in which the terminal operator prefers to raise its prices during some period, providing fewer services than those agreed upon and breaking the concession contract. On the other hand, if the concession agreement is awarded for a performance-based concession fee, then the greater the throughput volume handled by the terminal operator in one period is, the lower the concession fee charged by the port authority in the next period will be. The reduction of the concession fee could be seen as an implicit subsidy for the terminal operator's efforts. The researchers again compare the flow of profits when the terminal operator makes an effort to increase the throughput volume with the case in which the terminal operator only seeks to increase its own profits in a given portion of the concession period. From this analysis, they obtain the following results. On the one hand, if the demand faced by the terminal operator is relatively inelastic-for example, there is no close substitute available to port users - then the terminal operator tends to make no effort to improve quality and charge higher prices. Moreover, in the case of fixed lump-sum fees, a great market interest, short concession periods, and an unusually large one-time gain from cheating could lead a port terminal to break the concession contract earlier. Therefore, a fixed lump-sum concession fee is less efficient in combating the moral hazard problem. Finally, when performance-based fees are introduced, if the terminal operator is cheating, the opportunity cost is not only the future profit that the operator could have earned but also the deduction of concession fees over the subsequent periods. Consequently, this type of fee could be presented as a solution to the moral hazard problem. As the authors only consider a monopolistic framework, other factors such as competitive pressures are not taken into account as tools that could help to avoid or reduce moral hazard problems.

In contrast, to analyze the effect of competition on port concession agreements, Yip et al. (2014) study two ports competing in services that are close but imperfect substitutes and in which two private operators are applying for concession rights. The authors propound a two-stage game. In the first stage, each port must award its two terminals to one terminal operator, another terminal operator or both. Each port chooses the strategy that maximizes its profits which are a share of the terminals profit. Ports take rival's strategy into account, leading to four possible scenarios. In the first, each port is served by the two terminal operators. In the second, while each port is served by only one operator, these operators differ from the ports. Third, both ports are served by the same terminal operator. Finally, one port is served by one terminal operator and the other by both terminal operators. In the second stage, the terminal operators engage in a Cournot competition in each possible scenario. By comparing the equilibrium profits in each scenario, the best strategy for each port can be obtained. The problem is that these outcomes depend on many factors, so conclusions cannot be obtained straightforwardly. Despite this, they achieve the following conclusions. First, for a terminal operator, it is always preferable to monopolize the four terminals. Second, port authorities have incentives to introduce intra-port or inter-port competition only if their share of the terminal's revenues is large. Authors consider the share of revenues charged by 
ports as an exogenous parameter instead of a decision variable of port managers, this fact might have led to this unintuitive or confused result. Third, when ports are symmetrical but not perfect substitutes, every symmetrical outcome between ports could be a Nash equilibrium depending on such factors as the size of port demands, demand substitutability, and the proportion of revenues shared by the ports. When the results of a model depend on a branch of heterogeneous factors, a numeric simulation could be helpful to understand the model and to achieve additional results.

Saeed and Larsen (2010) analyze the effects of differentiated concession agreements on competition in three ports located in Pakistan (Karachi port, Port Muchammad Bin Qasin and Gwadar Port). In Karachi Port, there are three terminals, one public owned and the others operated by private companies. The concession conditions in this port for the private operators are not the same; unless both pay a fixed fee per TEU handled and an annual lease, the quantities are different. In the other two ports, there is only one terminal operator; additionally, Gwandar Port is new, and the concession conditions are not public. From a Bertrand oligopoly model, the authors obtained the Nash equilibrium prices and profits of the terminal operators in these ports (not including Gwandar port). Once the Nash equilibrium outcomes are obtained, the model is solved by a numerical simulation. To do this, authors use available information and the values of some parameters are assumed on the basis of previous studies. When the value of certain parameters are assumed, it would be desirable to test different values for these parameters in order to check the robustness of the results. Then, they compare the results of the present situation (concession contract with fixed fee differentiated by terminal) with two hypothetical scenarios in which the Karachi port authority does not discriminate between the two private terminal operators, with the same profits as in the real case. In the first scenario, the port authority sets the same fixed fee per TEU for both private operators, and in the second, the same percentage fee. Moreover, the gains in the users' surplus in the hypothetical cases from the real case are obtained applying the rule of the half ${ }^{3}$. The authors find that the profits of predominantly private companies located in Karachi port are lower with non-discriminatory fees than in the initial case. Nash equilibrium prices with a nondiscriminatory contract are higher in the fixed fee than in the percentage fee, with users better off with the non-discriminatory percentage fee.

Finally, Zheng and Negenborn (2014) analyze and compare vertical relations between government and port operators through two port regulation modes, centralization and decentralization. In the centralization model, government selects a port operator to manage port operations, designs the contract and receives all revenues, transferring a payment to the port operator. The central government requests cost information from the port operator to design the contract. So the contract is based on the port operator's report. Problems arise from the different objective functions of the agents and information asymmetries, which lead the authors to apply principalagent theory. Thus, the solution implies the central government designs a contract that maximizes social welfare, subject to the maximization of the port operator's profits only if the port operator reports truthful information, with profits being larger than in the case of cheating. Otherwise, decentralization mode is modeled as a Stackelberg game in which the local government plays the role of the leader, while the private port operator acts as a follower, competing with government's terminal in the port operators market. Authors assume that local government owns all relevant information about the port terminals' performance. Local governments are likely to have had more information about private terminals' performance than central government, even more if local government operates a public owned terminal, but even in this case, in practice, information asymmetries still occur between public and private agents. Moreover, the authors assume that private owned terminals are more cost-efficient than public owned ones. In the first stage, the local government sets the capacities of the public and private owned terminals. In the second stage, the 
local government and private operator set prices and efficiency levels playing a simultaneous duopoly game. This model is applied to container terminals in the Port of Shanghai, with the most important results as follows: decentralization reduces prices, and raises port efficiency, demand, and social welfare. The impact of different regulation modes on capacity and operators' profit is uncertain.

These studies investigating vertical relations are summarized in table 3.

\subsection{Horizontal relations between private port companies}

In this subsection, we reference works that analyze horizontal integration processes. Containerization and globalization of the world economy have encouraged the development of horizontal concentration or coalitions of port terminal operators. We can distinguish two cases: integration of private port operators that form part of a global port operator (for example, DP World which owns 46 port terminals over six continents or the equivalent) or coalitions or mergers that take place in the same port to gain market share, achieve better utilization of combined capacity and/or use partners' storage facilities (Saeed and Larsen, 2010). The latter has been studied empirically and theoretically by Reynaerts (2010) and Saeed and Larsen (2010), respectively. The first paper specifically analyzes the case of Hessenatie and NoordNatie, two private operators that carried out a merger in 2001, located in the port of Antwerp (Belgium). In the second paper, Saeed and Larsen analyze the possibility of coalitions among three terminals in Karachi port (Pakistan). Because we are surveying those works that apply game theory to the port industry, we focus on the latter.

Figure 4: Horizontal integration processes in port terminal industry

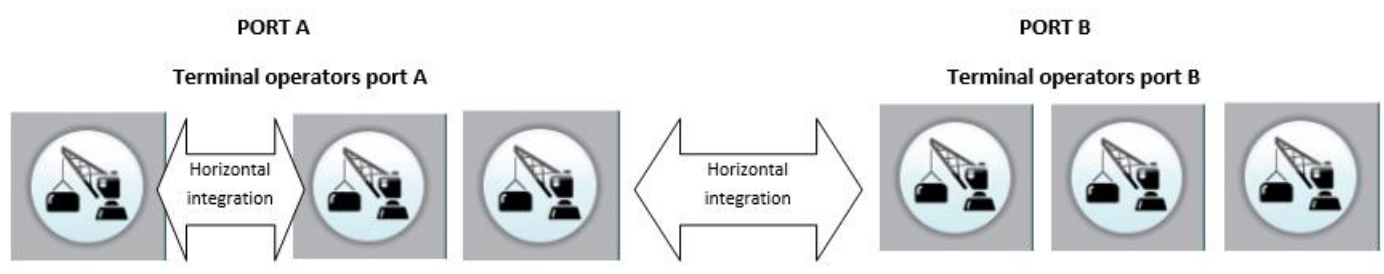

As stated, Saeed and Larsen (2010) analyze the decision of three terminal operators regarding whether to join a coalition, with one belonging to the port authority. Moreover, this port competes with another port in which there is only one terminal. In all coalition forms, the signatories decide cooperatively what prices to set and how to use their combined capacity to maximize the coalition surplus. Otherwise, coalitions and singletons compete in a non-cooperative way. For this purpose, they develop a two-stage game in which the market share of each terminal is derived by an aggregate multinomial logit model and demand for all the terminals is a function of the logsum ${ }^{4}$ from the logit model. In this game, first, the three terminals located in the same port decide in a non-cooperative way whether to join the coalition; this decision depends on the payoffs of the second stage, in which the terminals (signatories and singletons) compete in price. To do so, the game is solved by backwards induction. Therefore, the authors first derive reaction functions of the four terminals for the benchmark (no coalition) and all possible coalition scenarios. Then, with the available data, they solve the system of equation that forms the model in each scenario to obtain the prices' Nash equilibrium. From these prices, they obtain the equilibrium market shares, user costs, and profits. From the equilibrium profits, the authors test the stability of the different coalitions through the concepts of characteristic function and core $^{5}$. The stability analysis shows that there is a stable coalition; this is the grand coalition in which the three terminals obtain better 
payoffs than through any other coalition or being a singleton. Thus, in the first stage, the players should join the grand coalition. Authors have not considered how this grand coalition affects port authorities. If we assume that the port authorities are public owned, their objectives are likely to come into conflict with those of private owned terminals. For example, a public owned port authority cares about social welfare and the grand coalition raises prices and reduces demand shares, so consumer surplus is negatively affected. Thus, it would be interesting to analyze how coalitions affect the objectives of port authorities. Besides, it would be expected that port authorities react to coalitions when they set port fees or via the concession agreements. The study by Saeed and Larsen (2010) is summarized in table 4.

Some papers analyzed in this section consider that ports or port authorities share a part of private terminals revenues by a percentage fee. This assumption could be realistic when private owned ports are studied, but maybe not in the case of public owned port authorities. Sharing port terminals' revenue could degenerate the port authority's task of regulating prices to protect the public interest by linking private profits to public ones. Moreover, in practice, when ports charge private terminals a fee for the use of the infrastructure, it is usually a fixed sum fee (World Bank, 2007) instead of sharing terminal profits. So, in the case of public owned port authorities, this assumption seems not to be quite realistic or go in line with the general practices. 
Table 3: Summary of port authorities and terminal operators: vertical relations and horizontal integration processes

\begin{tabular}{|c|c|c|c|c|}
\hline & Objective & Relation and players & Methodology & Results \\
\hline $\begin{array}{l}\text { Van Reeven } \\
2010\end{array}$ & $\begin{array}{l}\text { Analyzing the effect of intra- } \\
\text { port competition on economic } \\
\text { sea rents }\end{array}$ & $\begin{array}{l}\text { - Integrated versus landlord ports } \\
\text { - Two ports competing } \\
\text { - N private terminal operators in each port } \\
\text { - Intra-port competition }\end{array}$ & $\begin{array}{l}\text { Two-stage game: } \\
\text { 1. Port authorities choose whether } \\
\text { ports are integrated or landlord } \\
\text { ports } \\
\text { 2. Authorities and private operators } \\
\text { simultaneously set port charges and } \\
\text { private prices competing in quantity. }\end{array}$ & $\begin{array}{l}\text { Being a landlord port is a Nash Equilibrium. } \\
\text { If the number of private operators in each port } \\
\text { tends to infinity, then port authorities' profits } \\
\text { are the same in both landlord and integrated } \\
\text { ports. }\end{array}$ \\
\hline $\begin{array}{l}\text { Kaselimi et } \\
\text { al. } 2011\end{array}$ & $\begin{array}{l}\text { Investigating the effects of a } \\
\text { dedicated terminal on inter- } \\
\text { and intra-port competition. }\end{array}$ & $\begin{array}{l}\text { - Vertical relation } \\
\text { - Two ports competing } \\
\text { - N and K terminal operators in each port } \\
\text { - Intra-port competition. }\end{array}$ & $\begin{array}{l}\text { One-stage quantity-price game: } \\
\text { Authorities and private operators } \\
\text { simultaneously set port charges and } \\
\text { private prices competing in quantity. }\end{array}$ & $\begin{array}{l}\text { Multi-user terminals are not negatively affected } \\
\text { by the introduction of a dedicated terminal. The } \\
\text { users of multi-user terminals always lose: prices } \\
\text { and congestion increase. }\end{array}$ \\
\hline $\begin{array}{l}\text { Yu and Shan } \\
2013\end{array}$ & $\begin{array}{lrr}\text { Analyzing } & \text { inter-port } \\
\text { competition and } & \text { vertical } \\
\text { relations between port } \\
\text { authority and terminal } \\
\text { operators }\end{array}$ & $\begin{array}{l}\text { - Vertical relation } \\
\text { - Two ports competing } \\
\text { - One terminal operator in each port } \\
\text { - Different terminal competition }\end{array}$ & $\begin{array}{l}\text { Three-stage game: } \\
\text { 1. Port authorities set port charges. } \\
\text { 2. Terminal operators determine } \\
\text { service quality centrally or } \\
\text { separately. } \\
\text { 3. Terminal operators set their prices } \\
\text { separately. }\end{array}$ & $\begin{array}{l}\text { Port authorities' profits are lower when terminal } \\
\text { operators are centralized. } \\
\text { A terminal with a disadvantage in service quality } \\
\text { would prefer to operate in a centralized way. }\end{array}$ \\
\hline $\begin{array}{l}\text { Wang and } \\
\text { Pallis } 2014\end{array}$ & $\begin{array}{l}\text { Providing a game theory } \\
\text { foundation for concession } \\
\text { agreements between port } \\
\text { authorities and private } \\
\text { operators. }\end{array}$ & $\begin{array}{l}\text { - Vertical relation (concession } \\
\text { agreements) } \\
\text { - One port authority } \\
\text { - One private operator }\end{array}$ & $\begin{array}{l}\text { Comparing flows of profits resulting from } \\
\text { cheating in the concession agreement in } \\
\text { a determined period with profits } \\
\text { obtained if the agreement is fulfilled. }\end{array}$ & $\begin{array}{l}\text { If port demand is inelastic, then terminal } \\
\text { operators put less effort into increasing } \\
\text { throughputs. } \\
\text { A fixed lump concession is less effective than a } \\
\text { performance-based fee, which could be } \\
\text { presented as a solution to a moral hazard } \\
\text { problem. }\end{array}$ \\
\hline $\begin{array}{l}\text { Yip et al. } \\
2014\end{array}$ & $\begin{array}{l}\text { Analyzing the effects of } \\
\text { competition on terminal } \\
\text { concession agreements. }\end{array}$ & $\begin{array}{l}\text { - Vertical relation } \\
\text { agreements) } \\
\text { - Two ports } \\
\text { - Two private operators. }\end{array}$ & $\begin{array}{l}\text { Two-stage game: } \\
\text { 1. Both ports decide which private } \\
\text { operator is awarded each of their } \\
\text { terminals. } \\
\text { 2. Terminal operators competing in } \\
\text { quantity. }\end{array}$ & $\begin{array}{l}\text { Terminal operators prefer to monopolize all } \\
\text { terminals. } \\
\text { Ports prefer to introduce intra- and inter-port } \\
\text { competition when the share of terminals' } \\
\text { revenues that they obtain is sufficiently large. }\end{array}$ \\
\hline
\end{tabular}


Table 3 (cont): Summary of port authorities and terminal operators: vertical relations and horizontal integration processes

\begin{tabular}{|c|c|c|c|c|}
\hline Study & Objective & - Relation and players & Methodology & Results \\
\hline $\begin{array}{l}\text { Saeed and } \\
\text { Larsen } 2010\end{array}$ & $\begin{array}{l}\text { Analyzing the effects } \\
\text { concession agreements } \\
\text { competition. }\end{array}$ & $\begin{array}{l}\text { - Vertical relation } \\
\text { agreements) } \\
\text { - Three ports in Pakistan. } \\
\text { - Five port terminals (three located in } \\
\text { Karachi port with different concession } \\
\text { conditions) }\end{array}$ & $\begin{array}{l}\text { One-stage game: Bertrand competition } \\
\text { between terminals in different } \\
\text { concession agreement scenarios. }\end{array}$ & $\begin{array}{l}\text { With non-discriminatory fees, the overall profits } \\
\text { of terminals located in Karachi are lower than } \\
\text { with discriminatory fees. } \\
\text { Users are better off with non-discriminatory } \\
\text { percentage fees. }\end{array}$ \\
\hline $\begin{array}{l}\text { Zheng and } \\
\text { Negenborn } \\
2014\end{array}$ & $\begin{array}{ll}\text { Comparing centralization } & \text { and } \\
\text { decentralization } & \text { port } \\
\text { regulation modes } & \end{array}$ & $\begin{array}{l}\text { - Vertical relation } \\
\text { - Centralization mode: } \\
\text { o Central government } \\
\text { o Private port operator } \\
\text { - Decentralization mode: } \\
\text { o Local government } \\
\text { o Private port operator }\end{array}$ & $\begin{array}{l}\text { Centralization mode: principal-agent } \\
\text { methodology. } \\
\text { Decentralization mode: two-stage game. } \\
\text { 1. Local government sets capacities } \\
\text { 2. Local government and private } \\
\text { operator set prices and efficiency } \\
\text { levels. }\end{array}$ & $\begin{array}{l}\text { Higher operational costs of port operator and/or } \\
\text { greater proportion of operator's profits from } \\
\text { governments' objective function have different } \\
\text { effects depending on the port regulation mode. } \\
\text { Centralization mode implies higher prices and } \\
\text { lower port efficiency, demand and social welfare. }\end{array}$ \\
\hline
\end{tabular}




\section{Port capacity investment}

A critical strategy for governments is the choice of port capacity. Port capacity expansion can reduce marginal cost in the presence of economies of scale in output and congestion. However, poor planning of capacity development can lead to misallocation of resources and loss of economic efficiency. In the critical economic situation currently affecting countries around the world, the development of efficient expansion strategies for ports is highly relevant, especially to justify public funding for these projects (Dekker and Verhaeghe, 2008). However, the opposite appears to be occurring in most ports. Ports around the world present overcapacity. Haralambides (2002) identifies such issues as economies of scale in port construction, capital indivisibilities, and port as an instrument of regional development, managerial "ego-boosting" and overly optimistic demand forecast as causes of overcapacity. Other authors note other factors, for example Luo et al. (2012) consider overcapacity as a reliability signal, using capacity investment as a preemptive policy to maintain or gain cargo traffic.

Models such as those developed by De Borger et al. (2008) and Xiao et al. (2010) seek to determine theoretically the optimal levels of port capacity that maximize the different objective functions of governments. These works are explained briefly to avoid repetition because they are described above. The first work models a two-stage game including investment in hinterland accessibility, and the second one uses a one-stage game in which ports simultaneously decide output, port charges and capacity considering different forms of ownership. These papers show that, on the one hand, greater private share in port ownership implies less capacity investment, while for a local government, higher spillover effect leads to higher optimal investment levels. On the other hand, they show that higher capacity investment increases the demand of that port, which invests reducing the demand of its competitor and port charges in both ports.

Luo et al. (2012) and Anderson et al. (2008) seek to explain the capacity investment process of two competitor ports in East Asia. In both papers, the process is first modeled, and then real data are applied to explain the model. The objective of these works is to assess whether the relevant governments should invest by comparing different investment scenarios. Luo et al. (2012) analyze pricing and capacity expansion as preemptive strategies. Whereas Anderson et al. (2008) only focus on capacity expansion as a strategy to defend or capture market share.

Luo et al. (2012) define a two-stage game. First, the government decides whether capacity expansion is carried out, assuming that a single government controls both ports because they are located in the same region. Moreover, capacity expansion occurs to the same extent in both ports, and it is common knowledge. Capacity expansion will be carried out only if the gain from the expansion exceeds its annualized capital cost. This gain depends on the competitor's capacity decision. Consequently, two possible gains from expansion may occur, on the one hand, when competitors do not invest and, on the other hand, when competitors invest. This leads to four decision rules, collected in figure 5, and sixteen possible scenarios. Each scenario could have one equilibrium, several equilibriums or no equilibrium. To check these scenarios, the authors carry out a numerical test. In the second stage, the ports compete following a Bertrand model with differentiated goods, taking into account the results obtained in the first stage and the competitors' strategy. The results obtained are the following. Firstly, a preemptive port charge under the equilibrium one is not credible. Secondly, higher port charge sensitivity and/or lower costs of the new port make the monopolist's preemptive port charge less effective. Thirdly, authors find that higher demand and market share increase the 
probability of capacity expansion, while a higher price sensitivity of the competitor has the opposite effect. Lastly, ports with higher costs, ceteris paribus, are more likely to invest in capacity to reduce their congestion cost. Once the model is defined, it is applied to the real case of competition between Hong Kong port and Shenzhen port. The investment decisions of these ports are coordinated by the government; however, private operators set prices. Applying real data, they find that Hong Kong (the incumbent port) cannot use the equilibrium preemptive price to prevent Shenzhen increasing its market share. Furthermore, Hong Kong should not expand its capacity, while Shenzhen should do so only if Hong Kong does not. Therefore, the authors conclude that when a new port has strong competitive advantages, pricing and capacity expansion preemptions are not effective. In that way, the best strategy for the former monopolist port is to increase its competitiveness.

Figure 5: Investment decision rules of each port

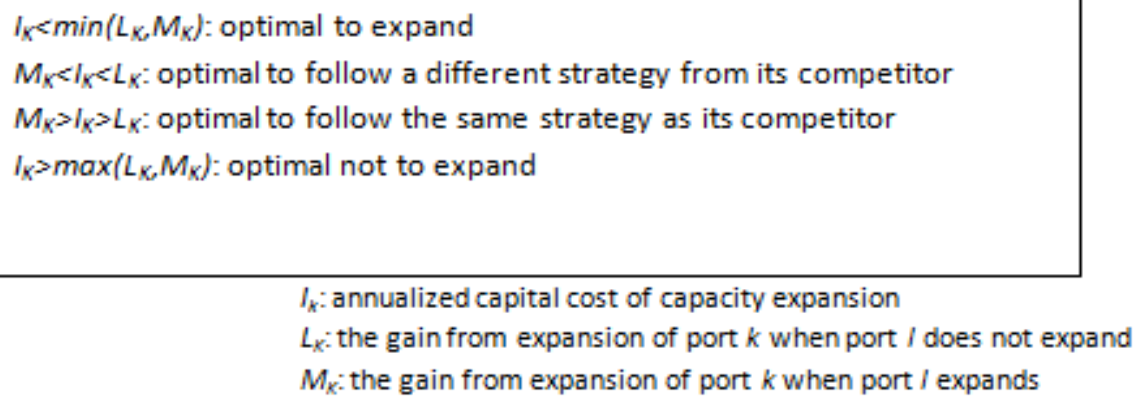

Source: Luo et al. (2012)

In the same line, Anderson et al. (2009) analyze how competitor ports will respond to the development of a port's additional capacity and whether this port will be able to capture or defend its market share. Although the aim of the work of Anderson et al. (2009) is similar to that realized by Luo et al. (2012), the methodology is different because the authors abstract away the pricing game due to the lack of information. So, they focus on the development game given observed or projected port charges. However, this fact does not eliminate the need for estimation of port demand because demand is needed to generate payoffs for different investment scenarios. Demand curve is built by using available data on Busan and Shanghai ports. In the capacity game, ports must decide whether to invest in infrastructure to attract more traffic or not. Thus, four possibilities are compared in different investment scenarios: neither port invest, both ports invest, only Shanghai invests, and only Busan invests. From profits generated by demand prediction, the model shows the investment best response strategy to competitor's strategy. As Luo et al. (2012), they consider the amount and cost of investment the same for both ports and common knowledge. The results suggest that it would be costly and unprofitable for Busan to seek to recover all its transshipment cargo lost to Shanghai's low-cost Yangshan terminal. In this way, development efforts should focus on traffic in which a significant competitive difference exists between the ports, i.e., those markets that are less vulnerable to capture by a rival with a lower-cost operation.

To the best of our knowledge, these studies are the first ones that take into account rivals investment strategies when a port decides to expand its capacity. The shortcoming of these 
models is that they impose a homogeneous capacity expansion for both ports. This assumption could not be realistic. Moreover, in both papers, strategic interdependence in setting capacity is analyzed in a discrete way. The works described above consider investment decisions as static choices. However, investment could be seen as a dynamic game because building extra port capacity requires long periods of time. This fact is taken into account by Ishii et al. (2013). 
Table 4: Summary of horizontal integration processes.

\begin{tabular}{|l|l|l|l|l|}
\hline Study & Objective & Model structure & Methodology \\
\hline $\begin{array}{l}\text { Saeed and } \\
\text { Larsen 2010 }\end{array}$ & $\begin{array}{l}\text { Analyzing different coalitions } \\
\text { among terminals located in } \\
\text { Karachi port. }\end{array}$ & $\begin{array}{l}\text { Two ports compete, with three } \\
\text { terminal operators. } \\
\text { Joining a coalition means that } \\
\text { terminals choose prices maximizing } \\
\text { the joint profit of the coalition. }\end{array}$ & $\begin{array}{l}\text { Two-stage game: } \\
\begin{array}{l}\text { Terminals of Karachi port decide } \\
\text { whether to join coalition or not. } \\
\text { Signatories compete in price in a non- } \\
\text { cooperative way }\end{array}\end{array}$ & $\begin{array}{l}\text { terminals of Karachi port) is stable, obtaining } \\
\text { better payoffs than in a any other strategy. }\end{array}$ \\
\hline
\end{tabular}


Although these authors do not specifically analyze investment decisions, they propose a model that allows the analysis of port charges in the timing of port capacity investment under interport competition and demand uncertainty. This model is applied to the real case of competition between Busan and Kobe ports. To do so, they consider a fixed finite time that is divided into different periods with varying lengths. At the beginning of those periods, port charges and capacity investment decisions take place. The authors assume that there is a leader port as the first mover in terms of capacity that invests in the odd periods, while the follower port expands its capacity in the even periods. Moreover, timing and levels of expansion are common knowledge. Otherwise, the authors assume that demand function fluctuates stochastically and port capacity expansion reduces external cost. Finally, it is assumed that ports reset their charges at the beginning of each period simultaneously, with port pricing behavior expressed by a jump process because it depends on capacity expansion, which is also a jump process. Therefore, each port sets charges at the beginning of a period to maximize the expected sum of discounted profits for this period where port profits depend on competitor behavior. Once all these assumptions are included in the model, the authors obtain the best response functions and derive the unique Nash equilibrium charges, obtaining some propositions. Finally, these propositions are applied to the inter-port competition case of Busan and Kobe. It would be interesting to include capacity as a decision variable of ports. As authors explain "it is important for each port to determine levels of port charges and port capacity from the viewpoint of port competition". Although this work is the only one in this survey that considers the dynamic nature of capacity expansions, capacity is not considered as a decision variable. The main findings of this work are summarized in the following propositions. If the average sum of surplus of consumers with the maximum willingness to pay is positive, then lower elasticity demands and higher capacity in both ports cause a decrease in the equilibrium port charges. In contrast, a long period between capacity investments increases Nash equilibrium charges. Data seem to confirm the first proposition. In the case of the second, data show that the proper action for Kobe port, likely to maintain its higher ranking, would have been to reduce port charges notwithstanding the length of capacity investment timing.

Table 5 summarizes these works related to port capacity.

\section{Government intervention and specialization}

Zhuang et al. (2013) propose port specialization as a possible solution to port overcapacity and excessive competition in port services. The main question for these authors is how specialization can be introduced and whether governments should intervene. Therefore, they build a model to investigate the factors or market conditions that affect port specialization. This paper is summarized in table 6. Their model features two competing ports that must decide which cargo to handle. There are only two types of cargo in the port industry, and ports can choose one or both types of cargo. Moreover, two different ways of competing in quantity are considered: Stackelberg and simultaneous. Due to ports' choices, different competitive scenarios can occur. Consequently, equilibrium prices, quantities and profits in all are obtained for comparison. In order to build a general analytical framework, authors just consider as determinants of specialization: market demand, the degree of substitutability between ports, and ports' costs. Other factors such as historical development paths, geographical differences, and productive specialization of the port hinterland or their current position in the market have not been taken into account in this model, but it should be modeled when a specific 
market is analyzed. They find that when the market size is sufficiently large, there is a clear advantage in terms of profit for the first mover. The authors note that this result can explain the aggressive port expansion in the Chinese port industry, with port investors believing that these investments can give them a competitive advantage. Another result shows that if a port faces moderate relative demand for a cargo, it does not provide this service under Stackelberg competition. Finally, port specialization is only possible in the following cases: firstly, natural specialization, which occurs when each port has a high relative demand for a different type of cargo; secondly, first-mover specialization, where if the follower port has a high relative demand for one cargo, it specializes in that cargo; and thirdly, specialization due to excess capacity, which could require government intervention. 


\section{Table 5: Summary of investment decisions}

\begin{tabular}{|c|c|c|c|c|}
\hline Study & Objective & Model structure & Methodology & Results \\
\hline $\begin{array}{l}\text { Luo et al. } \\
2012\end{array}$ & $\begin{array}{l}\text { Assessing whether preemptive } \\
\text { prices and investment could } \\
\text { work as entry barriers. }\end{array}$ & $\begin{array}{l}\text { - Two competing heterogeneous ports } \\
\text { (monopolist versus new port) } \\
\text { - Investment is the same for both ports } \\
\text { and common knowledge. }\end{array}$ & $\begin{array}{l}\text { Two-stage game: } \\
\text { 1. Ports decide whether to expand their } \\
\text { capacity. } \\
\text { 2. Ports set charges competing in prices. }\end{array}$ & $\begin{array}{l}\text { Preemptive port charge and investment are } \\
\text { not effective when the entrant port has high } \\
\text { competitive strength. }\end{array}$ \\
\hline $\begin{array}{l}\text { Anderson et } \\
\text { al. } 2008\end{array}$ & $\begin{array}{l}\text { Evaluating capacity expansion } \\
\text { as strategy to defend or } \\
\text { capture market share of Busan } \\
\text { and Shanghai ports. }\end{array}$ & $\begin{array}{l}\text { - Two ports competing } \\
\text { - Investment scenarios: } \\
\text { o To reduce turnaround times } \\
\text { o In additional gantry cranes } \\
\text { o In port terminals }\end{array}$ & $\begin{array}{l}\text { One-stage game: } \\
\text { 1. From estimated demand curve and } \\
\text { observed port charges, authors simulate } \\
\text { different types of investment in port } \\
\text { capacity and its effect on profits taking } \\
\text { into account competitor's strategy. }\end{array}$ & $\begin{array}{l}\text { It is not profitable for Busan to defend all the } \\
\text { transshipment cargoes it has lost to Shanghai. } \\
\text { Busan should focus its efforts on markets that } \\
\text { are less vulnerable to capture by Shanghai. }\end{array}$ \\
\hline $\begin{array}{l}\text { Ishii et al. } \\
2013\end{array}$ & $\begin{array}{l}\text { Developing a model to analyze } \\
\text { port charges in the timing of } \\
\text { port capacity investment } \\
\text { under inter-port competition. }\end{array}$ & $\begin{array}{l}\text { - Two ports competing. } \\
\text { - Fixed time of investment divided in } \\
\text { heterogeneous periods. } \\
\text { - At the beginning of each period, port } \\
\text { charges are set simultaneously, and } \\
\text { investment takes place. } \\
\text { - Leader port invests in odd periods, } \\
\text { follower in even ones. }\end{array}$ & $\begin{array}{l}\text { One-stage game: } \\
\text { 1. Port charges are set simultaneously at } \\
\text { the beginning of each period, obtaining } \\
\text { the best response functions and the } \\
\text { Nash equilibrium port charges. }\end{array}$ & $\begin{array}{l}\text { Whether the average sum of surplus of } \\
\text { consumers with the maximum willingness to } \\
\text { pay is positive, lower elasticity demands } \\
\text { and/or higher capacity in both ports implies } \\
\text { lower port charges. } \\
\text { The longer the period between capacity } \\
\text { investments is, the higher port charges are. }\end{array}$ \\
\hline
\end{tabular}


Table 6: Summary of port specialization.

\begin{tabular}{|c|c|c|c|c|c|}
\hline Study & Objective & Model structure & Variables & Methodology & Results \\
\hline $\begin{array}{l}\text { Tan et al. } \\
2013\end{array}$ & $\begin{array}{l}\text { Analyzing factors and } \\
\text { market conditions } \\
\text { behind specialization } \\
\text { decisions. }\end{array}$ & $\begin{array}{l}\text { - Two ports competing } \\
\text { - Two types of cargo in that } \\
\text { port industry. } \\
\text { - Stackelberg and Cournot } \\
\text { competing scenarios are } \\
\text { considered. }\end{array}$ & $\begin{array}{l}\text { - Prices } \\
\text { - Quantities } \\
\text { - Elasticities. } \\
\text { - Total cost of each type of } \\
\text { cargo: } \\
\text { o Marginal cost } \\
\text { o Fixed cost }\end{array}$ & $\begin{array}{l}\text { One-stage game. In each } \\
\text { scenario, ports choose quantities } \\
\text { that maximize their profits. }\end{array}$ & $\begin{array}{l}\text { Moving first is always preferred. } \\
\text { Specializations depend on relative } \\
\text { demand for each type of cargo. } \\
\text { Natural specialization, first-mover } \\
\text { specialization and specialization due } \\
\text { to excess capacity are the cases in } \\
\text { which specialization is possible. }\end{array}$ \\
\hline
\end{tabular}




\section{Conclusions and future research}

In this survey we have reviewed a collection of studies which use game theory approaches to analyze port competition and the strategies behind port managerial decisions. Port ownership, capacity investments, alliances, pricing or regulation are some of the topics that governments, port managers or terminal operators have to face. In this sense, the models presented in this survey have some policy and managerial implications related to them.

Notwithstanding, the main results of these models can be summarized as follow. Containerization and privatization have led to increased cargo movements and competition. Then, the study of optimal levels of port capacity has become a pivotal issue in port management. In this way, the models analyzed show that different forms of port ownership imply different levels of capacity investment. Capacity investment could not be a good strategy when competitors have high competitive strength. Moreover, hinterland infrastructures investment affects port strategies, and specialization could be a solution to overcapacity. Turning to devolution programs, they have introduced private operators in port activities. We have learnt that there may be a discrepancy between the welfare-optimal and private port participation. However, these models, with the exception of Zheng and Negenborn (2014), do not have taken into account the potential gains in efficiency associated to private operation. Moreover, as remark Zhang and Czerny (2012) for the case of airports, these results can change when port concession revenues exist. In fact, a deeper understanding on how port concession revenues may change previous results should be desirable. On the other hand, if we consider the existence of asymmetric information among the different port agents, a performance-based fee could be a solution to the moral hazard problem.

However, in spite of game theory could be a useful tool to study the strategic decisions and interactions in port industry, it presents some shortcomings. On the one hand, the high number of port agents that participate in port activities complicates the application of game theory to the port sector. So, in order to simplify reality to develop a model, these models may not collect the complexity of all factors of the sector. In this sense, it would be useful to test empirically the theoretical models. This would yield stronger insights about port agents' performance. However, this would require the availability of statistical interactions in port industry, it presents some shortcomings. On other hand, given that the use of game theory applied to the analysis of port economics is quite recent, there is no consensus about the way to model port competition. In this sense, each contribution to the literature presents a different way to pose the problem. A clear example is the development of port demand functions, which differs from one study to another, despite being determinant on model results. In this way, the results are not always consistent between the works analyzed because of the techniques used or the differences on the port environment of the countries of study. A stronger debate on the appropriate assumptions and more careful attention to the port's institutional specifics is highly desirable. Therefore, results from such theoretical models should be taken with the appropriate caution. In this sense, much more work is necessary to achieve a unified methodology which allows connecting the different models or issues analyzed.

Finally, future research should include the robustness of the main results from theoretical models using different specifications for port demand and congestion functions, port's institutional specifics and the empirical application of the models. Other new lines of research could be: (1) the analysis of investment decisions when competing ports share the same 
hinterland infrastructures, (2) the study of the effects of different forms of ownership considering vertical separation of port services, (3) a deeper analysis of non-price inter port competition, (4) the study of vertical relationships under a two side network ${ }^{6}$ framework $^{2}$ (Rochet and Tirole, 2003).

\section{Notes}

${ }^{1}$ To achieve more homogeneity in concepts, we use port charge to refer to the amount of money charged by ports or port authorities against a ship or its cargo in port, price to refer to the amount of money charged by the terminal operator for handled services and, finally, port fee to refer to the amount of money that terminal operators must pay to port authorities for port land. When we must talk in general terms, we use the concept of price or pricing.

${ }^{2} \mathrm{~A}$ dedicated terminal is that port capacity that a port authority dedicates for exclusive use by a specific customer or group of customers.

${ }^{3}$ According to 'the rule of the half' methodology, a change in user surplus can be estimated as a change in the generalized costs multiplied by the average demand before and after the formation of a new contract.

${ }^{4}$ The logsum is defined as the log of the sum of the exponential of the port terminals' utility functions. It is a measure of consumer surplus in the context of logit choice models (De Jong et al., 2007).

${ }^{5}$ A characteristic function allocates each coalition a real number, called the coalition value. This value represents the minimum value that a coalition can obtain when all its members cooperate and act like a team. In contrast, the core is a set of imputations under which no coalition has a value greater than the sum of its members' payoffs (Song and Panayides, 2002).

${ }^{6}$ A two side network or market is an economic platform that have to distinct group of users. This platforms provide infrastructure and rules that facilitate the two groups' transactions generating a virtuous circle. Providing services to one group of users generate positive externalities to the other one (Eisenmann et al., 2006).

\section{References}

Anderson, C. M., Park, Y. A., Chang, Y. T., Yang, C. H., Lee, T. W. andLuo, M. (2008) A gametheoretic analysis of competition among container port hubs: the case of Busan and Shanghai. Maritime Policy \& Management 35(1): 5-26.

Baird, A. J. (2000) Port privatization: objectives, extent, process, and the UK experience. Maritime Economics \& Logistics 2(3): 177-194.

Basov, S. (2001) Hamilton approach to multi-dimensional screening. Journal Mathematical Economics 36: 77-94.

Basso, L. J., and Zhang, A. (2008) Congestible facility rivalry in vertical structures. Journal of Urban Economics 61(2): 218-237.

Basso, L. J., Wan, Y. and Zhang, A. (2013) Seaport competition and strategic investment in accessibility. 10 In CongresoChileno de Ingeniería de Transporte (No. 16). 
Brooks, M.R. (2004) The governance structure of ports. Review of Network Economics 3(2): 168-183.

Cariou, P. (2008) Liner shipping strategies: an overview.International Journal of Ocean Systems Management 1(1): 2-13.

Carlin, A., and Park, R. E. (1970) Marginal cost pricing of airport runway capacity.The American Economic Review, 60(3): 310-319.

Chang, Y. T., and Lee, P. T. (2007) Overview of interport competition: Issues and methods. Journal of International Logistics and Trade, 5(1): 99-121.

Cheon, S., Dowall, D. E., and Song, D. W. (2010) Evaluating impacts of institutional reforms on port efficiency changes: Ownership, corporate structure, and total factor productivity changes of world container ports. Transportation Research Part E: Logistics and Transportation Review, 46(4): 546-561.

Czerny, A., Höffler, F.andMun, S. I. (2014) Hub port competition and welfare effect of strategic privatization. Economics of Transportation, 3(3): 211-220.

De Borger, B., Proost, S. and Van Dender, K. (2008) Private Port Pricing and Public Investment in Port and Hinterland Capacity.Journal of Transport Economics and Policy 42(3): 527-561.

De Jong, G., Daly, A., Pieters, M., and Van der Hoorn, T. (2007) Thelogsum as an evaluation measure: review of the literature and new results. Transportation Research Part A: Policy and Practice 41(9): 874-889.

Dekker, S. and Verhaeghe, R. J. (2008) Development of a strategy for port expansion: an optimal control approach. Maritime Economics \& Logistics 10(3): 258-274.

Eisenmann, T., Parker, G., \& Van Alstyne, M. W. (2006) Strategies for two-sided markets. Harvard business review, 84(10), 92.

European Central Bank. Emerging economies. Available in : https://www.ecb.europa.eu/ecb/tasks/international/emerging/html/index.en.html

Ferrari, C., andBenacchio, M. (2000) Market structure in container terminal operators and port services. Paper presented in IAME 2000 Conference, 13-15 September, Napoli, Italy.

Frémont, A. (2009) Empirical Evidence for Integration and Disintegration of Maritime Shipping, Port and Logistics Activities. (No. 2009/1). OECD Publishing.

Haralambides, H. E. (2002) Competition, excess capacity, and the pricing of port infrastructure. International Journal of Maritime Economics 4(4): 323-347.

Ishii, M., Lee, P. T. W., Tezuka, K. and Chang, Y. T. (2013) A game theoretical analysis of port competition.Transportation Research Part E: Logistics and Transportation Review 49(1): 92106.

Kaselimi, E. N., Notteboom, T. E. and De Borger, B. (2011) A game theoretical approach to competition between multi-user terminals: the impact of dedicated terminals. Maritime Policy \& Management 38(4): 395-414. 
Levine, M. E. (1969) Landing fees and the airport congestion problem. Journal of Law and Economics 12(1): 79-108.

Luo, M., Liu, L. and Gao, F. (2012) Post-entry container port capacity expansion. Transportation Research Part B: Methodological 46(1): 120-138.

Matsushima, N., andTakauchi, K. (2014) Port privatization in an international oligopoly. Transportation Research Part B: Methodological 67: 382-397.

Midoro, R., Musso, R. and Parola, F. (2005) Maritime liner shipping and the stevedoring industry: market structure and competition strategies. Maritime Policy \& Management 32: 89106.

Minju, B. (2013) A game theory approach to analyzing container transshipment port competition. PhD Thesis. National University of Singapore.

Pallis, A. A., Vitsounis, T. K., and De Langen, P. W. (2010). Port economics, policy and management: Review of an emerging research field. Transport Reviews, 30(1): 115-161.

Pérez-Navarro, J., Jimeno-Pastor, J.L. and Cerdá-Tena, E. (2004) Teoría de Juegos. Pearson Education, S.A. Madrid.

Reynaerts, J. (2010) Simulating mergers between stevedores. Maritime Economics \& Logistics 12(1): 8-35.

Rochet, J.C. and Chone, P.(1998) Ironing, sweeping and multidimensional screening. Econometrica 66 (4): 783-826.

Rochet, J. C., \& Tirole, J. (2003) Platform competition in two-sided markets. Journal of the European Economic Association, 1(4): 990-1029.

Rodal, A. and N. Mulder (1993) Partnerships, Devolution and Power-sharing: Issues and Implications for Management. Optimum, The Journal of Public Sector Management 24: 27-48.

Ryoo, D. K. andThanopoulou, H. A. (1999) Liner alliances in the globalization era: a strategic tool for Asian container carriers. Maritime Policy \& Management 26(4): 349-367.

Saeed, N. and Larsen, O. I. (2010) An application of cooperative game among container terminals of one port. European Journal of Operational Research 203(2): 393-403.

Song, D. W. andPanayides, P. M. (2002) A conceptual application of cooperative game theory to liner shipping strategic alliances. Maritime Policy \& Management 29(3): 285-301.

Soppé, M., Parola, F. and Frémont, A. (2009) Emerging inter-industry partnerships between shipping lines and stevedores: from rivalry to cooperation?. Journal of Transport Geography 17(1): 10-20.

Suykens, F., and Van de Voorde, E. (1998) A quarter a century of port management in Europe: objectives and tools. Maritime Policy and Management 25(3): 251-261. 
Tongzon, J. and Heng, W. (2005) Port privatization, efficiency and competitiveness:Some empirical evidence from container ports (terminals). Transportation Research PartA 39: 405424.

Van de Voorde, E. and Vanelslander, T. (2009) Market Power and Vertical and Horizontal Integration in the Maritime Shipping and Port Industry. (No. 2009/2). OECD Publishing.

Van Reeven, P. (2010) The effect of competition on economic rents in seaports. Journal of Transport Economics and Policy 44(1): 79-92.

Wan, Y., and Zhang, A. (2013) Urban road congestion and seaport competition. Journal of Transport Economics and Policy 47(1): 55-70.

Wang, G. W., andPallis, A. A. (2014) Incentive approaches to overcome moral hazard in port concession agreements. Transportation Research Part E: Logistics and Transportation Review 67: 162-174.

Xiao, Y., Ng, A. K., Yang, H., and Fu, X. (2012) An analysis of the dynamics of ownership, capacity investments and pricing structure of ports. Transport Reviews 32(5): 629-652.

Yang, Z. (1995) Stackelberg equilibrium analysis of container cargo behavior. Journal of the Eastern Asia Society for Transportation Studies 1: 249-261.

Yang, Z. (1996) An application of Stackerlberg problem to international container movement. Proceeding of the 1st JSPS-NUS Seminar on Integrated Engineering: 125-134.

Yang, Z. (1998) Research on the strategy of developing container terminals. PhDThesis, Kobe University.

Yang, Z. (1999) Analysis of container port policy by the reaction of an equilibrium shipping market. International Journal of Maritime Policy and Management, 26(4): 369-381.

Yip, T. L., Liu, J. J., Fu, X., and Feng, J. (2014) Modeling the effects of competition on seaport terminal awarding. Transport Policy 35: 341-349.

Yu, M., and Shan, J. (2013) A Hotelling model approach to container port competition. In Service Systems and Service Management (ICSSSM), 2013 10th International Conference on: 253-258. IEEE.

Yuen, A., Basso, L.J. and Zhang, A. (2008) Effects of gateway congestion pricing on optimal road pricing and hinterland. Journal of Transport Economics and Policy 42(3): 495-526.

Zan, Y. (1999) Analysis of container port policy by the reaction of an equilibrium shipping market. Maritime Policy \& Management 26(4): 369-381.

Zhang, A. (2008) The impact of hinterland access conditions on rivalry between ports. OECD Publishing (No. 2008/8).

Zhang, A. and Czerny, A. I. (2012) Airports and airlines economics and policy: an interpretive review of recent research. Economics of Transportation, 1(1): 15-34. 
Zheng, S. and Negenborn, R.R. (2014) Centralization or decentralization: A comparative analysis of port regulation modes. Transportation Research Part E: Logistics and Transportation Review 69: 21-40.

Zhuang, W., Luo, M. and Fu, X. (2013) Does Chinese Port Industry Need More Regulation?-A Game Theory Analysis of Port Specialization. In International Forum on Shipping, Ports and Airports (IFSPA) 2013: Trade, Supply Chain Activities and Transport: Contemporary Logistics and Maritime Issues. 